\title{
Modeling of content and language integrated learning for students of economics
}

\author{
Elena Rodionova ${ }^{1}$, Svetlana Firsova ${ }^{1}$, and Fliura Garifullina ${ }^{1}$ \\ ${ }^{1}$ Volga State University of Technology, 3 Lenin sq., Yoshkar-Ola, 424000, Russia
}

\begin{abstract}
The English language is considered to be the global language of communication and professional activity in the field of Economics. One of the effective techniques of professional communicative competence is Content and Language Integrated Learning (CLIL). The aim of the research is to elaborate the model of CLIL for students of Economics at the Volga State University of Technology. Such methods as theoretical (literature review, analysis, generalization, comparison, interpretation, analogy, modeling), general empiric (study and generalization of teaching practices), specific empiric (questionnaires, testing, observation, documents review) statistical (processing of questionnaires and testing results) proved successful in the course of research. The undertaken research allowed identifying the interest of the majority of teachers and students of Economics in using the English language when teaching and learning some subject-matter disciplines. Consequently, it is possible to make a conclusion concerning the necessity of taking some special measures such as preliminary language courses, meeting the organizational and financial requirements. The research results have allowed to establish that the intermediate (according to the scale 'soft-hard') subject-led model is the most appropriate for the implementation in the educational process of students of Economics at the Volga State University of Technology. For this purpose, the authors elaborated the conceptual didactic CLIL model.
\end{abstract}

\section{Introduction}

In the context of globalization, the linguistic competence is considered to be the essential factor for a person well-being. The multilingual individual is becoming a 'link' between a culture and a language [1]. Due to the internalization of the society the significance of student foreign language fluency is constantly increasing. The high level of communicative competence gives graduates an opportunity to be valuable members of the international scientific, cultural and professional community. The global trends of the modern system of education, connected with the internalization of the human life and post-industrial society formation, requires the high level of language proficiency $[2,3]$. The significance of multilingual education for Russia is closely connected with the necessity of world collaboration in dealing with global problems, implementation of international projects in the different fields of human activity.

Nevertheless in a majority of Russian educational institutions a foreign language as an academic discipline is 'isolated' from other subjects and has tenuous content and logic 
relations with them. The durability of foreign language learning is usually limited up to $2-3$ years. The lack of regular language practice leads to the academic decline, while the majority of graduates the need and requirement for the proficiency in foreign languages (primarily in English). It is especially true for the students of economics.

One of the effective technologies for professional and communicative competence development is Content and Language Integrated Learning (CLIL). CLIL gives an opportunity to integrate learning of foreign languages and subject matter disciplines during the whole period of university studies to maintain the sustainable level of foreign language proficiency and its further enhancement.

Besides, the researchers specially underline the CLIL potential for the development of metadisciplinary competences, knowledge and skills. These competences play a special part for the specialists in the economic field due to the necessity to deal with the huge information flow, identify essential data, solve various problems within the dynamic outside environment, be engaged in teamwork.

In higher educational institutions of Russia CLIL is used while teaching various disciplines for students of different specialties [4-9]. The given paper is devoted to the study of CLIL implementation for teaching students of Economics at Volga State University of Technology.

The purpose of the research is to develop and validate the Model of CLIL for the students of Economics.

Nowadays the notion of Content and Language Integrated Learning has various interpretations and there are more than 40 definitions only in European studies [4].

The term Content and Language Integrated Learning (CLIL) was launched in Europe in the 1990s by members of the EuroCLIC Network, a group of experts from different backgrounds, including educational administrators, researchers, and practitioners [10]. D. Marsh (University of Jyväskylä, Finland) is considered to be the most prominent representative of this group. He is the author of such papers as 'Profiling European CLIL Classrooms: Languages Open Doors'[11].

CLIL refers to any dual-focused educational context in which an additional language is used as a medium in the teaching and learning of non-language content [12]. CLIL describes an evolving approach to teaching and learning where subjects are taught and studied through the medium of a non-native language ("TKT: Teaching Knowledge Test", 2009). The book [Coyle et al., 2010] provides a succinct definition that refers to its specific features: "Content and Language Integrated Learning (CLIL) is a dual-focused educational approach in which an additional language is used for the learning and teaching of both content and language". Thus, CLIL can include a wide range of educational practices provided that these practices are conducted through the medium of an additional language and both language and the subject have a joint role [4]. It is an umbrella term for a whole variety of approaches [12], but whatever the approach, it is a major issue that the content on the topic or theme leads the way. One of the critical features that differentiates CLIL from LSP is that in the former content is new, relevant and cognitively challenging. Thus, CLIL is not language teaching enhanced by a wider range of content. The key idea of CLIL is its two-focused direction both to the teaching content through foreign language, and to the teaching foreign language through content.

The research studies show that CLIL provides higher academic output and contributes to the development of a person of a new generation. The adequate implementation of CLIL results in developing the skills necessary for a competitive specialist. The subject-matter content in the foreign language, learnt with the help of active and interactive methods increases student motivation, encourages developing necessary competences and gaining significant outcomes. 


\section{Methods}

The following research methods were used: (1) theoretical (searches and generalization of the literature in the field of research, synthesis, comparison, specification, interpretation, analogue approach, modeling); (2) general empiric (analyses and evaluation of best practices); (3) specific empiric (questionnaire, testing, observation, document analyses), (5) statistics (processing the results of questionnaire and testing).

The validity of questionnaire and testing was based on the organizational, psychological conditions for CLIL implementation within the particular educational institution, teachers and students commitment playing the important part in this process. The subjective and objective commitment should be differentiated.

One of the criteria of teachers and students availability for CLIL implementation is considered to be their level of English language proficiency. The subjective commitment is closely connected with the students and teachers readiness and motivation to apply English in teaching and learning subject-matter disciplines. The level of the English language proficiency was evaluated by means of testing. The subjective commitment was studied by a specially designed questionnaire.

The test of English was supposed to meet following requirements validity, lack of testing fees, correspondence to CEFR (Common European Framework of Reference).

As a result, EF SET (https://www.efset.org/free-english-test) was chosen for testing as a standardized test of English evaluating language proficiency in accordance with CEFR. Test EF SET includes 2 modules: 'Reading' and 'Listening'. The test is adaptive to the level of language proficiency of the particular candidate.

\section{Results}

In accordance with the results of testing more than a half of three and four-year students of Economics correspond to A2 (CEFR,) nearly $25 \%$ of students - A1 (Table 1, Figure 1).

Table 1. Distribution of students in accordance with the level of English proficiency and average grade.

\begin{tabular}{|c|c|c|c|c|c|c|c|c|c|c|c|c|}
\hline \multirow{2}{*}{ Index } & \multicolumn{3}{|c|}{ Level A1 } & \multicolumn{3}{c|}{ Level A2 } & \multicolumn{3}{c|}{ Level B1 } & \multicolumn{3}{c|}{ Level B2 } \\
\cline { 2 - 12 } & Total & $\mathbf{1 - 2 5}$ & $\mathbf{2 6 - 3 0}$ & Total & $\mathbf{3 1 - 3 5}$ & $\mathbf{3 6 - 4 0}$ & Total & $\mathbf{4 1 - 4 5}$ & $\mathbf{4 6 - 5 0}$ & Total & $\mathbf{5 1 - 5 5}$ & $\mathbf{5 6 - 6 0}$ \\
\hline $\begin{array}{c}\text { Propor } \\
\text { tion, } \\
\%\end{array}$ & 224.1 & 00,0 & 224.1 & 551.7 & 224.1 & 227.6 & 117.2 & 113.8 & 33.4 & 77.0 & 33.5 & 33.5 \\
\hline
\end{tabular}

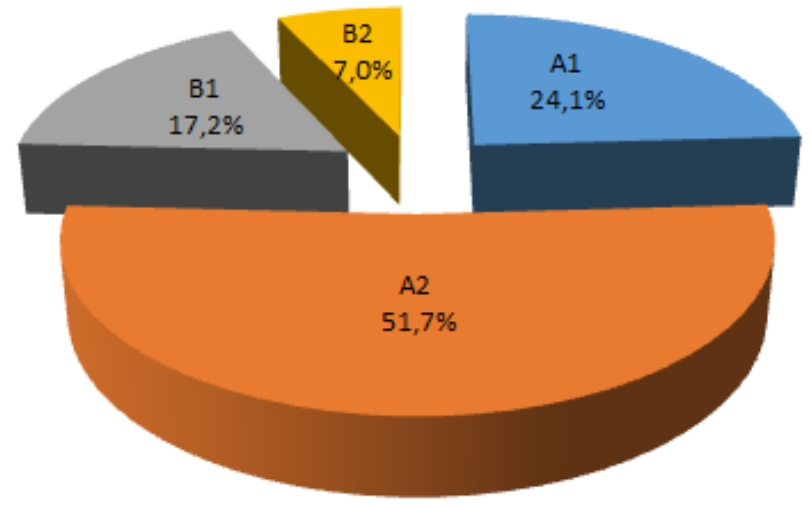

Fig. 1. Proportion of the distributed students' English proficiency level. 
The arithmetic average of the students results is 36.5 . The modal average for the variation series with the interval of 10 is 35.4 .The modal average for the variation series with the interval of 5 is 37.3 .

The median average calculated for the variation series with the interval of 10 is equal to 36.0. The median average calculated for the variation series with the interval of 5 is 36.3 .

Thus, the arithmetic averages, mode and median, are approximately equal and correspond to A2 level for the majority of students.

It should be pointed out that, the majority of students demonstrated a high level of listening skills $(86.2 \%)$, in spite of the material complexity. The grades for listening turned out to be higher than the ones for reading (Table 2).

Table 2. Correlation of grades for different language activities.

\begin{tabular}{|c|c|c|c|}
\hline Index & $\begin{array}{c}\text { Grades for listening are } \\
\text { higher than grades for } \\
\text { reading }\end{array}$ & $\begin{array}{c}\text { Grades for listening are } \\
\text { lower than grades for } \\
\text { reading }\end{array}$ & $\begin{array}{c}\text { Grades for listening and } \\
\text { reading are equal }\end{array}$ \\
\hline Proportion, \% & 86.2 & 10.3 & 3.5 \\
\hline
\end{tabular}

The average grade for reading is 31.5 with the maximum of 58 and the minimum of 23 grades. The average grade for listening corresponds to 40.9 with the maximum of 59 and the minimum of 26 grades.

There are no definite requirements to the level of English proficiency for students in CLIL. Teachers and lecturers share their educational experience of teaching students of different levels [7].

It is obvious that A1 Level is not sufficient for the adequate education in CLIL. The fact that the majority of the students has A2 Level demands special language, tools, techniques and methods of teaching.

We share the opinion that students should have at least B1 Level for achieving successful results in CLIL, otherwise, due to the 'theory of two thresholds' there will be negative effect on the learning outcomes. Hence, in some cases additional classes of English will be of help.

The questioning of the students was held before the testing with the paper questionnaires. The questionnaire contained questions concerning students' opinion on different aspects of CLIL. Besides, the results of testing were also included to the questionnaire.

It was found out that $31.0 \%$ of students took additional classes apart from school and university training. But there was no correlation between additional education and the level of English proficiency of students.

No students study subject-matter disciplines or their modules in English, but $34.5 \%$ of respondents has some experience of attending lectures conducted by foreign speakers. In particular, $80.0 \%$ pointed that they had certain difficulties with understanding and asking questions.

More than a half of respondents show interest to English as a language of studying subject-matter disciplines. But there was no correlation between the level of interest and exhibited English proficiency. Apparently, some other factors such as students' plans and ambitions, motivation are intended to play a more significant role (Table 3 ). 
Table 3. Students' answers illustrating their intention to study subject-matter disciplines in English.

\begin{tabular}{|c|c|c|c|c|c|c|c|c|c|c|c|c|c|c|c|}
\hline \multirow[t]{2}{*}{ Index } & \multicolumn{3}{|c|}{$\begin{array}{c}\text { With A1 } \\
\text { Level }\end{array}$} & \multicolumn{3}{|c|}{$\begin{array}{c}\text { With A2 } \\
\text { Level }\end{array}$} & \multicolumn{3}{|c|}{$\begin{array}{c}\text { With B1 } \\
\text { Level }\end{array}$} & \multicolumn{3}{|c|}{$\begin{array}{c}\text { With B2 } \\
\text { Level }\end{array}$} & \multicolumn{3}{|c|}{ Total } \\
\hline & Total & Yes & No & Total & Yes & No & Total & Yes & No & Total & Yes & No & Total & Yes & No \\
\hline Proportion, $\%$ & 1100 & 771.4 & $\begin{array}{c}228 \\
, 6\end{array}$ & 1100 & 440.0 & $\begin{array}{c}660 \\
, 0 \\
\end{array}$ & 1100 & 880.0 & $\begin{array}{c}220 \\
, 0\end{array}$ & 1100 & 550.0 & $\begin{array}{c}550 \\
0\end{array}$ & 1100 & 555.2 & $\begin{array}{c}444 . \\
8 \\
\end{array}$ \\
\hline
\end{tabular}

Due to the content aspects of economic subjects we are of the view that it is the teachers of subject-matter disciplines who should implement CLIL for students of Economics.

The commitment of subject-matter teachers to implementing CLIL was evaluated with the help of specially designed questionnaires. The questionnaire included some items reflecting teachers' opinions to some aspects of CLIL implementation.

The first question was concerned with the level of English proficiency (CEFR). The results are presented in Table 4.

Table 4. of teachers according to the level of English proficiency.

\begin{tabular}{|c|c|c|c|c|c|}
\hline Index & $\begin{array}{c}\text { No } \\
\text { proficiency in } \\
\text { English }\end{array}$ & LevelA1 & Level A2 & Level B1 & Level B2 \\
\hline Proportion, \% & 10.0 & 10.0 & 10.0 & 50.0 & 20.0 \\
\hline
\end{tabular}

CLIL researchers consider that CLIL can be efficiently implemented only by teachers win levels B2-C1 [13]. The results show that only $20 \%$ of respondents stated level B2 (the highest one).

A half of the respondents completed the additional course "Researcher-translator".

However, only few respondents have some educational experience in practical usage of English, namely text translation, communication with foreign students, examination test translation, translation the content of the e-course.

$70 \%$ of teachers believe that conducting subject-matter disciplines in English is quite appropriate. $30 \%$ of respondents consider it not to be reasonable. $60 \%$ of teachers would agree to deliver their subjects in English if financial and managerial conditions are provided. All participants consider the variant of "including particular theme and issues" as the most appropriate.

Thus, the undertaken research identified the interest of the majority of the teaching staff of Economics to the CLIL implementation and the necessity of special measures to be initiated in terms of managerial and financial support.

\section{Discussion}

Having considered all possible CLIL variants, implemented in higher educational institution [14], and taken into account some features of educational programs as the level of teaching staff and students commitment we suggested considering 'soft-hard' CLIL variant (subject-led model).

We also believe that 2 or 4 hours per week is the most appropriate schedule time for studying special modules or themes. It seems to be especially reasonable and adequate for the initial period of CLIL implementation. Later on it is possible to deliver subject-matter disciplines completely in English.

For successful implementation of CLIL educational potential it is necessary to work out the conceptual model on the basis of the CLIL theory and methodology.

It should be pointed out that the notion "conceptual model" was introduced in engineering psychology in 1961 by A. Welfordy. In his opinion, conceptual model is a 
particular integrate image of the process which allows to bring into connection its different parts.

Currently, the conceptual model is understood as an abstract model of the modeled system consisting of different elements, their features and interconnections.

On the basis of the results of the research, we suggest including such elements of the CLIL conceptual model as target, content, subjective, procedure, assessment.

The target component contains the target and goals of the Content and Language Integrated Learning.

The goals specify a set of competences acquired by students of Economics when implementing CLIL. In accordance with the Federal State Educational Standard and Professional Standard (FSOSHE 3++) the competence model of the graduate of Economics includes universal, general professional and professional competences.

The content component of the model includes the theoretical and methodological background of Content and Language Integrated Learning and a set of disciplines conducted with CLIL elements. The methodology of CLIL deals with interdisciplinary integration, cognitive "theory of two thresholds", Model 4 (5) 'C' (Content, Communication, Cognition, Culture/Citizenship,(Competence)), theory 'BICS/CALP', B.Bloom's taxonomy of cognitive skills, competence approach [15].

In accordance with these considerations the subject-matter disciplines for CLIL elements were selected. We consider it to be reasonable to exclude elective disciplines, which can vary due to the choice of students. It should be taken into account that developing and conducting the course in English is significantly more labour-intensive than in Russian, that is why this process has to be implemented within several years. There were also identified particular disciplines for which CLIL implementation was restricted to only certain modules, themes or issues. We recommend to combine subject-matter discipline of the first and second group at the first stage of CLIL implementation.

The subjective component is connected with the CLIL academic body. We believe that it is teachers of subject-matter disciplines who should implement CLIL (subject-led variant) at the technical university.

Teachers of the subject-matter disciplines in Economics have a high level of competences in the field of special subjects but lack sufficient proficiency in English. Thereupon it would be desirable and value-added for them to take a preparatory course of English.

It is also necessary to organize and promote interaction and collaboration between teachers of English and those of special subjects for the sake of validity of study materials (texts, tasks, tests).

The procedure component includes strategies, modes, methods, techniques of CLIL.

The implementation of CLIL methodology is based upon the tutorial strategies developed by O. Meyer.

The key strategy is "scaffolding" aimed at the overall support of students with the help of a range of educational "pillars" allowing to decrease cognitive and linguistic load of Content and Language Integrated Learning. The strategy 'make it H.O.T' is focused on the development of the higher order thinking skills through the set of questions corresponding to different levels of Bloom taxonomy. The strategy 'rich input' primarily deals with the choice of study materials, texts, practical exercises. The adequate study materials for implementing CLIL principles should be authentic, personally oriented, geared towards the development of both lower and higher-order thinking skills. They should also contain cultural and multicultural components ('adding the (Inter-) cultural dimension') to provide students with the information on different approaches to the content in accordance with different cultures and scholars. While using the appropriate language students have 
possibility to practice special vocabulary in friendly educational environment and be quite independent in English proficiency [16].

The modes of CLIL process include traditional forms of language learning - individual, pair, group activities, as well as seminars, lectures, independent work with the study materials and electronic courses.

The learning methods include both traditional (explanatory illustrative, reproductive) and active and interactive (case-study, projects, rotation, 'flipped' classroom).

CLIL is implemented by means of co-focusing on the authentic study materials, content, interaction within co-operative, active and interactive learning with provision of students autonomy [17].

We can recommend such techniques as 'Warm-up', 'Brainstorming', 'Grab it!', 'Question Loop', 'True-False Dictation', 'Loop or Domino Game', 'Plenary' as the most appropriate and effective for teaching subject-matter disciplines of Economics [19].

The set of special means of CLIL in accordance with the suggested model will include e-courses, printed hands-outs, and textbooks.

It can be distinguished the following main requirements to the CLIL study materials: the compliance with the educational and CLIL aims, training stage, cognitive skills level, scaffolding maintenance, motivation of personal development, aims and goals achievability, coverage of the main issues [20].

The assessment component of the suggested model covers the issues of assessing the skills being formatted and outputs achieved. The system of learning outputs assessment is one of the problematic aspects of CLIL.

Due to the studies of best practices teachers pay particular attention to the summative rather than formative assessment (assessment of learning).

Summative assessment deals with students' knowledge and skills at the definite period of education (module, term, and semester) and is usually carried out as a formal testing.

Formative assessment is more complicated, informal and aimed at further development of a learner and its planning (assessment for learning). Formative assessment also implies students' feedback and deals with students' motivation and interest to the learning process. The results of the formative assessment allow to tailor the learning process to the definite student [19].

The graphical presentation of the model under consideration is illustrated in Figure 2. The study programs of Economics are notated as the following: "Accounting, Auditing and Analysis" - specialization 1, "Finance and Credit" - specialization 2, "Economics and Management in organizations (enterprises)" - specialization 3. 

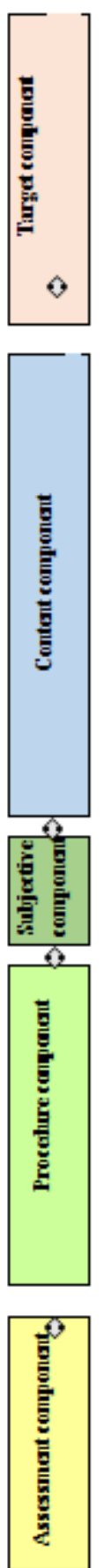

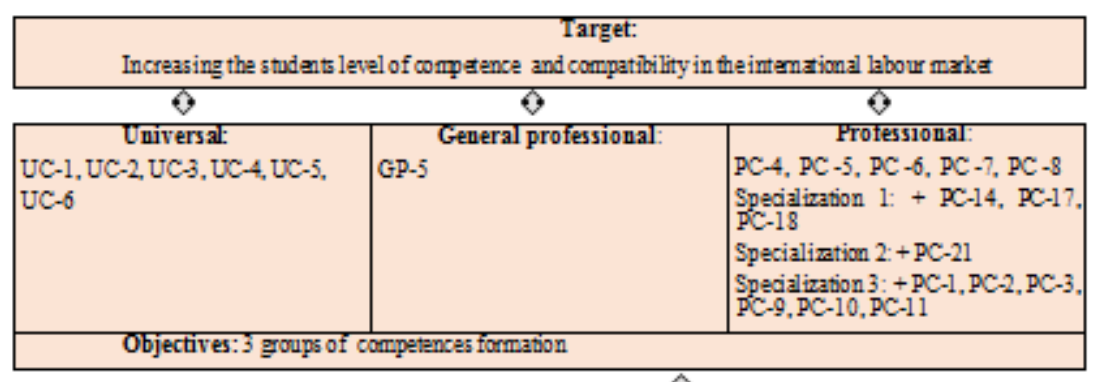

Theoretical and methodological bacloground:

- Interdisciplinary integration

- Cognitue theory of two thresholds"

- Model 4 (5) 'C' (Content,

Colture Citizanship.

(Competence))

- Theory 'BICS CAIP'

- BBloom's tawonony of cognitive skills

- Competence approach
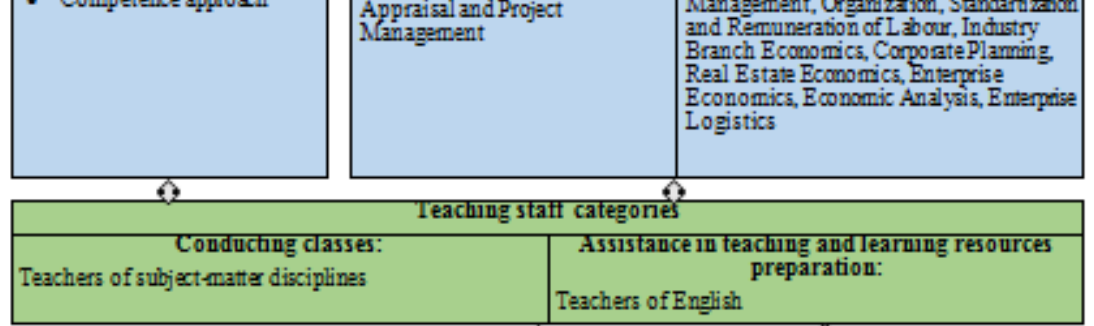

\begin{tabular}{|c|c|c|c|}
\hline \multirow[b]{2}{*}{\begin{tabular}{|l} 
Strategres: \\
- Scaffolding \\
Nake it HOT. \\
Rich input \\
Adding the (Inter-) \\
cultualdinension \\
Rich interaction
\end{tabular}} & \multicolumn{2}{|c|}{8} & 69 \\
\hline & $\begin{array}{l}\text { Modes: } \\
\text { - Individual, pair, group } \\
\text { - Lectures, seminars, } \\
\text { practical classes } \\
\text { - Independent wodk with } \\
\text { study materials and e- } \\
\text { courses }\end{array}$ & $\begin{array}{l}\text { Mrethods: } \\
\text { - Traditional (explanatory } \\
\text { illustrative, reproductive) } \\
\text { - Active and interactive } \\
\text { ('round-table' mathod, } \\
\text { projects, case study, } \\
\text { rotation, } \\
\text { classroom') }\end{array}$ & \begin{tabular}{|l|} 
Techuiques \\
Wam--up. Bainstorming, \\
Grab it, Question Loop, \\
True-False Dictation, Loop \\
or Domino Gane, Plenary
\end{tabular} \\
\hline$\theta$ & $\theta$ & $\theta$ & $\theta$ \\
\hline $\begin{array}{l}\text { - E-courses of the universi } \\
\text { - Printed hands-outs and }\end{array}$ & $\begin{array}{l}\text { ducational portal } \\
\text { oobs }\end{array}$ & & \\
\hline
\end{tabular}

- Printed hande-outs and textboobs

\begin{tabular}{|c|c|}
\hline \multicolumn{2}{|c|}{ Assessment of 3 groups of competences } \\
\hline \multirow{3}{*}{$\begin{array}{l}\text { - Universal } \\
\text { - General professional } \\
\text { - Professional }\end{array}$} & Formative \\
\hline & Assessment for leaming \\
\hline & $\begin{array}{l}\text { Summative } \\
\text { Assessment of leaming }\end{array}$ \\
\hline$\theta$ & $\theta$ \\
\hline
\end{tabular}

Fig. 2. Conceptual model of CLIL for the students of the educational program 38.03.01 of the FSBEI of Higher Education 'Volga State University of Technology'. 


\section{Conclusion}

The authors hope that the implementation of the suggested model into the educational process of the students of the educational program 38.03.01 of the FSBEI of Higher Education "Volga State University of Technology" will result in increasing the students level of competence and compatibility in the international labor market. Due to the research more than a half of students are quite interested in English as a language of studying subject-matter disciplines and the majority of the teachers $(70 \%)$ consider conducting subject-matter disciplines in English appropriate and reasonable. Thus, the research proved the availability of the majority of the teaching staff and student body to the 'soft-hard' CLIL variant (subject-led model).

The research materials are of special interest for higher education institutions focused on increasing their graduates' competitiveness due to the use of innovative educational technologies.

\section{References}

1. A.A. Isakova, Retrospective Analysis of Communicative Competence Development. Integration of education, 1(21), 46-53. http://dx.doi.org/10.15507/19919468.086.021.201701.046-053 (2017)

2. M. Ivanova, N. Mekeko, T. Kashkarova, N. Shlenskaya, The Influence of the Teaching Style of Communication on the Motivation of Students to Learn Foreign Languages. Journal of Language and Education, 5(2), 67-77. https://doi.org/10.17323/jle.2019.9695 (2019)

3. N.S. Godzhaeva, T.A. Logunov, M.S. Lokteva, S.A. Zolotareva, Approaching CLIL from the Periphery: Integration of Content and Language in Russian Higher Education Institution. European Journal of Contemporary Education, 2019, 8(2), 280-293. http://dx.doi.org/10.13187/ejced.2019.2.280 (2019)

4. K.S. Grigor'eva, Formirovanie u studentov tekhnicheskogo vuza inoyazychnoj kompetencii v sfere professional'noj kommunikacii na osnove tekhnologii CLIL [Professional Foreign Language Competence Formation on the basis of CLILat Technical University] (Unpublished candidate dissertation). Kazan Federal University, Kazan, (2016)

5. L.P. Halyapina, Sovremennye tendencii v obuchenii inostrannym yazykam na osnove idej CLIL [Contemporary trends in foreign languages teaching on the basis of CLIL]. Voprosy metodiki prepodavaniya v vuze, 6 (20), 46-52. http://dx.doi.org/10.18720/HUM/ISSN 2227-8591.20.5. (2017)

6. N.V. Popova, M.S. Kogan, E.K. Vdovina, Predmetno-yazykovoe integrirovannoe obuchenie (CLIL) kak metodologiya aktualizacii mezhdisciplinarnyh svyazej v tekhnicheskom vuze [Content and Language Integrated Learning (CLIL) as a Methodology of Interdisciplinary Links Mainstreaming in Technical Higher Educational Institution. Vestnik Tambovskogo universiteta. Seriya: Gumanitarnye nauki, 173(23), 29-42.http://dx.doi.org/10.20310/1810-0201-2018-23-173-29-42 (2018)

7. E.G. V'yushkina, Opyt ispol'zovaniya predmetno-yazykovogo integrirovannogo obucheniya $v$ yuridicheskom vuze [The practice of language-content integrated learning using in Law higher educational school]. Nauchnyj vestnik Voronezhskogo gosudarstvennogo arhitekturno-stroitel'nogo universiteta. Seriya: Sovremennye lingvisticheskie i metodiko-didakticheskie issledovaniya, 2(26), 82-92. (2015) 
8. L.P. Halyapina, Sovremennye tendencii v obuchenii inostrannym yazykam na osnove idej CLIL [Contemporary trends in foreign languages teaching on the basis of CLIL]. Voprosy metodiki prepodavaniya v vuze, $6(20), 46-52$. http://dx.doi.org/10.18720/HUM/ISSN 2227-8591.20.5 (2017).

9. R.R. Zaripova, L.L. Salehova, M.N. Tyukareva, Integrirovannyj predmetno-yazykovoj podhod (CLIL) v obuchenii matematike [Content and Language Intergraded Approach (CLIL) in Teaching Mathematics]. Mezhdunarodnyj zhurnal eksperimental'nogo obrazovaniya, 11-4, 506-509. (2015)

10. J. Cenoz, F. Genesee, D. Gorter, Critical Analysis of CLIL: Taking Stock and Looking Forward. Applied Linguistics, 35 (3), 243-262. http://dx.doi.org/ 10.1093/applin/amt011 (2014)

11. D. Coyle, Ph. Hood, D. Marsh, Content and Language Integrated Learning. Cambridge: Cambridge University Press, (2010)

12. P. Mehisto, D. Marsh, M. J. Frigols, Uncovering CLIL. Content and Language Integrated Learning in Bilingual and Multilingual Education. Oxford: Macmillan Education, (2008)

13. L.K. Salnaya, Sovershenstvovanie professional'noj kompentnosti professorskoprepodavatel'skogo sostava universiteta $\mathrm{v}$ oblasti predmetno-yazykovogo integrirovannogo obucheniya [Developing of Teaching Staff Professional Competence in the Field of Content and Lanuage Integrated Learning]. Filologicheskie nauki. Voprosy teorii i praktiki, 12(78), 206-209, (2017)

14. S.A. Grigoryan, E.A. Lebedeva, Osobennosti vnedreniya modeli integrirovannogo ovladeniya soderzhaniem obucheniya i inostrannym yazykom v rossijskuyu obrazovatel'nuyu sistemu [Special aspects of content-lanuage integrated model implementation in educational system of Russia].Nauka i obrazovanie: hozyajstvo i ekonomika; predprinimatel'stvo; pravo i upravlenie, 5(48), 17-21, (2014).

15. E.V. Rodionova, Metodologicheskie osnovy predmetno-yazykovogo integrirovannogo obucheniya v vysshej shkole [Methodological Foudations of Content and Language Integrated Learning in Higher School]. Nauka i perspektivy, 4. Retrieved from http://nip.esrae.ru/pdf/2018/4/10.pdf (2018)

16. N.I. Batrova, L.L.Salehova, Pedagogicheskij eksperiment po obucheniyu informacionno-kommunikacionnym tekhnologiyam v shkole na bilingval'noj osnove [Pedagogical Experiment on Information Technologies Teaching at School on Bilingual Basis]. Istoricheskaya i social'no-obrazovatel'naya mysl',6 (22), 52-57, (2013)

17. E.A. Cimerman, N.I. Almazova, Professional'no-orientirovannoe posobie po anglijskomu yazyku s elementami CLIL dlya studentov-menedzherov [Professionally oriented textbook in English with CLIL-elements for students of management]. Voprosy metodiki prepodavaniya v vuze, 6(20), 72-79. http://dx.doi.org/10.18720/HUM/ISSN 2227-8591.20.8 (2017)

18. TKT: Teaching Knowledge Test: Handbook for Teachers (Content and Language Integrated Learning). Cambridge: Cambridge University Press, (2009)

19. L.S. Pichkova, Rol' predmetno-yazykovogo integrirovannogo obucheniya (CLIL) v formirovanii novyh obrazovatel'nyh tekhnologij v vysshej shkole [Significance of content-language integrated learning (CLIL) in the formation of new educational technologies in higher school]. Chelovecheskij capital, 8(104), 71-74, (2017). 